\title{
Genetic parameters for milk somatic cell score and relationship with production and udder type traits in dairy Alpine and Saanen primiparous goats
}

\author{
R. Rupp, ${ }^{* 1}$ V. Clément, † A. Piacere, † C. Robert-Granié, ${ }^{\star}$ and E. Manfredi* \\ *INRA, UR631, F-31326 Castanet-Tolosan, France \\ †Institut de l'Elevage, F-31326 Castanet-Tolosan, France
}

\section{ABSTRACT}

Goat milk somatic cell counts have been collected for several years in France by the national milk recording organization. Information is used for health management, because repeatedly elevated somatic cell counts are a good indirect predictor of intramammary infection. Genetic parameters were estimated for 67,882 and 49,709 primiparous goats of the dairy Alpine and Saanen breeds, respectively, with complete information for milk somatic cell counts and milk production traits. About $40 \%$ of the goats had additional information for 11 udder type traits scored by official classifiers of the breeders' association CAPGENES. Estimates were obtained by REML with an animal model. The studied trait was lactation somatic cell score (LSCS), the weighted mean of somatic cell score (log-transformed SCC) adjusted for lactation stage. Heritability of LSCS was 0.20 and 0.24 in the Alpine and Saanen breeds, respectively. Relationships with milk production and udder type traits were additionally estimated by using multitrait analyses. Heritability estimates in first lactation ranged from 0.30 to 0.35 for lactation milk, fat, and protein yields; from 0.60 to 0.67 for fat and protein contents; and from 0.22 to 0.50 for udder type traits. Genetic correlations of somatic cell score with milk production traits were generally low, ranging from -0.13 to 0.12 . Slightly more negative correlations were estimated for fat content: -0.18 and -0.20 in Saanen and Alpine breeds, respectively. Lactation somatic cell score was genetically correlated with udder floor position $\left(\mathrm{r}_{\mathrm{g}}\right.$ $=-0.24$ and -0.19 in the Alpine and Saanen breeds, respectively), and, in Saanen, teat length, teat width, and teat form $\left(\mathrm{r}_{\mathrm{g}}=0.29,0.34\right.$ and -0.27 , respectively). These results suggest that a reduction in somatic cell count can be achieved by selection while still improving milk production and udder type and teat traits.

Received August 8, 2010.

Accepted March 22, 2011.

${ }^{1}$ Corresponding author: Rachel.Rupp@toulouse.inra.fr
Key words: somatic cell count, genetic parameter, dairy goat

\section{INTRODUCTION}

Milk SCC has been used widely in dairy ruminants as an indirect predictor of udder health status. Indeed, milk SCC mainly reflects the number of neutrophils that migrate from blood to the mammary gland in response to infection. As in dairy cattle or sheep, an increase in SCC has been reported in goat as a consequence of infection (Poutrel et al., 1997; Paape et al., 2001; Bergonier and Berthelot, 2003; Bergonier et al., 2003; Luengo et al., 2004; Moroni et al., 2005; Koop et al., 2010). Because the frequency of clinical mastitis is very low in dairy goats, relationships between SCC and mastitis were established using milk bacteriology examination. Contreras et al. (1996), for instance, reported that 500,000 cells/mL was a useful threshold to discriminate between infected and uninfected udder halves. It is difficult, however, to interpret single SCC measures and to define fixed infection thresholds because numerous factors influence the SCC of infected and noninfected animals, such as age and physiological status of the host, infection stage, and pathogen (Paape et al., 2001; Bergonier et al., 2003; Luengo et al., 2004; Moroni et al., 2005; Koop et al., 2010). Distributions of SCC of infected or noninfected animals overlap considerably. Furthermore, the ability of milk SCC to predict intramammary infection is lower in goat than in cattle and sheep (Poutrel and Lerondelle, 1983; Boettcher et al., 2005). Accordingly, prediction rules would be better based on repeated SCC measures over a lactation, as proposed by De Crémoux and Poutrel (2001). The latter authors suggest using several SCC measures over lactation and 2 thresholds, of 750,000 and 1,750,000 cells $/ \mathrm{mL}$, to discriminate between uninfected animals, animals infected with minor pathogens, and animals infected with major pathogens. With these rules, they achieved a sensitivity of 61 to $83 \%$ and a specificity of 61 to $80 \%$. Such prediction, although imperfect, can 
be used efficiently for prophylactic purposes, including culling of persistently infected animals.

Somatic cell count can be recorded at low cost in routine milk recording, whereas direct mastitis diagnosis is more expensive. Recording of SCC has been extensively developed in dairy cattle and in several dairy sheep populations. In those species, evidence is accumulating that SCC is under genetic control (Mrode and Swanson, 1996; el-Saied et al., 1999; Rupp and Boichard, 2003; Rupp et al., 2003). Accordingly, many countries (Rupp et al., 2002; Miglior et al., 2005) have updated their breeding objective to include a linear decrease of milk SCC as a tool to decrease both subclinical and clinical intramammary infections. Results from a divergent selection experiment in dairy sheep suggest that SCC-based selection can efficiently decrease the rate, duration, and severity of intramammary infections with staphylococci (Rupp et al., 2009). Considering SCCbased selection in dairy goat for improved udder health, however, requires accurate estimates of genetic parameters for goat milk SCC that are not currently available in peer-reviewed papers.

The objective of this study was to estimate heritability for milk SCC and genetic correlations between SCC and currently selected traits (milk production and udder type) in Alpine and Saanen goats.

\section{MATERIALS AND METHODS}

\section{Data}

Data originated from Alpine and Saanen goats first kidding between September 1, 1998, and August 31, 2003. Only SCC data collected in A-type sampling schemes as part of the official milk recording system were used; that is, milk samples from evening and morning milkings were mixed before chemical analysis. Somatic cell counts were measured by using a Fossomatic cell counter (Foss Electric, Hillerød, Denmark) at interprofessional milk analysis laboratories. The SCC data were stored in regional genetic information centers and were extracted for the present genetic analysis. The SCC information consisted of an average of 6 individual SCC per lactation collected on a monthly basis. Data on SCC were then merged with pedigree and milk production information from the national goat database of the CTIG (Processing Centre of Genetic Information, Jouy en Josas, France).

As natural mating is predominant in goats, edits were applied to maximize connections between flocks. Disconnectedness affects the estimates of variance components, especially when the genetic level is variable among flocks (Clément et al., 2001). In the goat populations studied, several groups of farms were identified with different genetic levels given by their mating and replacement policies. Sires could be from the national AI scheme or sons of AI bucks or sons of natural mating bucks. Dams could be daughters of AI bucks, granddaughters of AI bucks, or unrelated to AI bucks. Connected flocks by year were defined as flock-by-year combinations with at least one daughter sired by a connecting AI buck. Connecting bucks had to have at least 20 daughters raised in at least 5 different flock-years. Accordingly, 67,882 and 49,709 Alpine and Saanen goats from 1,814 and 1,324 flock-years, respectively, were selected. Alpine and Saanen goats were sired by 2,624 and 2,125 bucks, respectively, $7 \%$ of them ensuring connection among flocks via AI.

Of those selected animals, 24,388 Alpine (36\%) and 18,741 Saanen (44\%) goats were scored by official classifiers of the breeders' association CAPGENES (Mignaloux Beauvoir, France) for 11 udder type traits during first or second lactation: fore udder, udder profile, udder floor position, teat length, teat width, teat form, teat angle, teat placement, teat orientation, rear udder, and rear udder attachment, as was previously detailed by Manfredi et al. (2001).

\section{Definition of SCC, Milk Production, and Udder Type Traits}

Test-day SCC were transformed to SCS by a classical logarithmic transformation (Ali and Shook, 1980) to achieve normality of distribution. A mean lactation somatic cell score (LSCS) was computed as the weighted arithmetic mean of test-day SCS adjusted for DIM, following the procedure developed for French dairy cattle (Boichard and Rupp, 1997). Briefly, adjustment factors for DIM at each test were estimated using a quadratic function of time for a subset of goats likely to be unaffected by mastitis. Unaffected goats were selected according to diagnosis rules established by De Crémoux and Poutrel (2001); that is, with all test-day SCC (between 1 and 235 DIM), except 1, below 750,000 cells $/ \mathrm{mL}$. Adjustment factors should therefore mainly reflect the dilution effect of DIM. They were estimated independently for the 2 breeds. Adjusted test-day SCS were then averaged using the ratio $\mathrm{R}_{d} / \sigma_{d}$ as weighting factor, where $d$ was the lactation stage in months $(d=$ 1 to 8 stages, up to $240 \mathrm{~d}$ in milk), $\mathrm{R}_{d}$ was the correlation between test-day SCS at stage $d$ and the average of the other SCS measured during first lactation, and $\sigma_{d}$ was the standard deviation of SCS at stage $d$. The highest $\mathrm{R}_{d} / \sigma_{d}$ ratios were for SCS collected between 60 and 180 DIM. Those weights and adjustments should accommodate a lack of strict periodicity in the recording design and the variability in the number of records available. 
Table 1. Structure and descriptive statistics of the data set (goats kidding between September 1, 1998, and August 31, 2003)

\begin{tabular}{lcc}
\hline Item & Alpine & Saanen \\
\hline Primiparous goats, n & 67,882 & 49,709 \\
Flock-years, n & 1,814 & 1,324 \\
Bucks, n & 2,624 & 2,126 \\
Means (SD) of traits if first lactation: & & \\
Lactation SCS & $5.09(1.36)$ & $5.32(1.19)$ \\
Milk yield, ${ }^{1} \mathrm{~kg}$ & $668(158)$ & $698(178)$ \\
Protein yield, ${ }^{1} \mathrm{~kg}$ & $20.9(4.9)$ & $21.0(5.3)$ \\
Fat yield, ${ }^{1} \mathrm{~kg}$ & $24.4(6.3)$ & $23.7(6.8)$ \\
Protein content, $\mathrm{kg} / \mathrm{L}$ & $31.4(2.5)$ & $30.1(2.1)$ \\
Fat content, $\mathrm{kg} / \mathrm{L}$ & $36.5(4.8)$ & $33.9(4.5)$ \\
\hline
\end{tabular}

${ }^{1}$ In a 250 -d lactation.

Milk production traits were those considered for genetic evaluation (Clément et al., 2002): 250-d lactation for milk, fat, and protein yields $(\mathrm{kg})$ and fat and protein contents $(\mathrm{g} / \mathrm{kg})$. Udder type traits were linear scores from 1 to 9 , and included measured traits such as teat length and teat width (Manfredi et al., 2001). They were considered as continuous quantitative traits with a single measure per animal. Characteristics of the data set are summarized in Table 1.

\section{Method}

Variance components for LSCS were estimated separately in the Saanen and Alpine breeds with REML applied to multitrait animal models, using the VCE package (Neumaier and Groeneveld, 1998). Genetic and environmental correlations of LSCS with production traits and udder type traits were estimated by multivariate REML using 2-trait analyses because of computing requirements. Four generations of ancestors were traced back with the relationship matrix, resulting in a total number of animals of 162,121 and 121,411 for the Alpine and the Saanen goats, respectively.

For LSCS and the 5 milk production traits recorded in first lactation, the model included, as fixed effects, the combination between year of kidding and flock (1,814 and 1,324 levels in Alpine and Saanen breeds, respectively), the combination between age at kidding and year (25 levels), and the combination between kidding month and year (28 levels), and the random effect of animal.

For udder type traits, the model included, as fixed effects, the interaction between flock, year, and parity (1,646 and 1,225 levels in Alpine and Saanen breeds, respectively), the interaction between age at scoring and year (73 levels), the interaction between lactation stage and year (84 levels), and the random effect of animal. The flock-year-parity interaction included the classifier effect as scoring of each flock-year was done by a single classifier.

\section{RESULTS AND DISCUSSION}

\section{Descriptive Statistics}

Averages of milk somatic score (LSCS) in primiparous goats were $5.1( \pm 1.4)$ and $5.3( \pm 1.2)$ in the Alpine and Saanen breeds, respectively (Table 1), corresponding to an average SCC of about 1,000,000 cells $/ \mathrm{mL}$. Those levels are in the range of SCC values usually reported in dairy goats, as reviewed by Bergonier et al. (2003) in 3 Spanish, Italian, and French dairy goat populations. Lower values are reported in various sheep breeds (Bergonier et al., 2003) and in dairy cattle. For instance, average values of LSCS in French primiparous Holstein (Rupp and Boichard, 1999) and French primiparous Lacaune dairy sheep (Rupp et al., 2003) were $2.6(1.2)$ and 3.1 (1.5), respectively.

The prevalence of intramammary infections and the type of pathogens (mainly staphylococci) are rather similar in the 3 dairy species, except for the higher frequency of clinical mastitis in dairy cattle (Bergonier et al., 2003). High SCC levels in goat are probably due, at least to some extent, to the importance of lentiviral mastitis and to noninfectious factors of inflammation such as parity, stage of lactation, or season (Paape et al., 2001).

\section{Genetic Parameters for LSCS}

Genetic parameters for LSCS are reported in Table 2. Heritability was 0.20 and 0.24 for the Alpine and Saanen breeds, respectively. The higher value for the Saanen breed resulted from a lower environmental variance. To our knowledge, this is the first published report on genetic parameters for SCC in goat. Conversely, in dairy cattle and sheep, estimates of genetic parameters for SCC have been published over the past 2 decades. Heritability of LSCS in goat was slightly higher than the published heritability for cattle, around 0.15, as reviewed earlier (Mrode and Swanson, 1996; 
Table 2. Genetic parameters $( \pm \mathrm{SE})$ for lactation SCS in primiparous Saanen ( $\mathrm{n}=49,709)$ and Alpine $(\mathrm{n}=67,882)$ goats (means of five 2-trait analyses including each 1 of the 5 milk production traits)

\begin{tabular}{lcc}
\hline Parameter & Saanen & Alpine \\
\hline Heritability & $0.24 \pm 0.01$ & $0.20 \pm 0.01$ \\
Genetic variance & $0.30 \pm 0.01$ & $0.31 \pm 0.01$ \\
Environmental variance & $0.93 \pm 0.01$ & $1.26 \pm 0.01$ \\
\hline
\end{tabular}

Rupp and Boichard, 2003) and for dairy sheep, around 0.13 (El-Saied et al., 1999; Barillet et al., 2001; Rupp et al., 2003; Serrano et al., 2003; Legarra and Ugarte, 2005; Riggio et al., 2007). This higher heritability in goats might be the consequence of a higher true genetic variability (genetic variances in Table 2 were higher than corresponding typical values for cows). In addition, the choice of connected data prevented biases, under- or overestimation, of true genetic parameters as shown in simulation studies (Clément et al., 2001). Environmental variances were lower than those reported in other studies on small ruminants (e.g., Barillet et al., 2001; Rupp et al., 2003). One explanation is the standardized conditions of the field data used here, evening and morning sampling each month, and the consequent amount of information on each goat, with an average of 6 records per lactation. Including later lactations could have yielded somewhat lower heritabilities than those reported here. In this regard, we plan to expand on the present study to include lactations $>1$ and random regression models of analysis (Reents et al., 1995). Moreover, an ongoing experiment in the experimental farm of INRA Bourges (France) is designed to study the relationships between SCS, clinical mastitis, and infectious status for divergent lines selected for extreme LSCS.

\section{Relationships with Production Traits}

Heritabilities for milk production traits (Table 3) were close to previous French estimates in the same breeds (Bélichon et al., 1998). Genetic correlations between LSCS and milk production traits were generally low (Table 3). In the Alpine breed, genetic correlations with milk yield and protein yield were not significantly different from zero $(P>0.05)$. Genetic correlations, however, were slightly positive, and therefore unfavorable, in the Saanen breed (0.06 to 0.12). On the contrary, correlations with fat content and with fat yield (only in the Alpine breed) were significantly $(P<0.05)$ negative and favorable.

Genetic antagonism between milk yield and SCS has been consistently reported in dairy cattle (Mrode and Swanson, 1996) and in some sheep breeds (Rupp et al., 2003; Riggio et al., 2007), but the antagonism found in goats was limited, especially in the Alpine breed.

\section{Relationships with Udder Type Traits}

Genetic parameters for udder type traits and genetic correlations $\left(\mathbf{r}_{\mathrm{g}}\right)$ with LSCS are summarized in Table 4. Heritabilities for udder type traits were in close agreement with 2 previous reports in French Saanen and Alpine goats (Manfredi et al., 2001; Clément et al., 2006). In general, genetic associations of LSCS with udder and teat traits were moderate.

Genetic correlations were significantly $(P<0.05)$ negative for udder floor position in the 2 breeds $\left(\mathrm{r}_{\mathrm{g}}=\right.$ -0.24 in Alpine and $r_{g}=-0.19$ in Saanen), indicating that better attached udders were associated with lower cell counts. Consistently, udder depth has generally shown the most reliable results across species, breeds, and studies, indicating that higher and more tightly attached udders are associated with lower SCC (review by Rupp and Boichard, 2003). Udder depth can therefore be considered as an easy-to-collect predictor of udder health. In addition, higher udder floor position was genetically associated with lower milk production in previous studies (Manfredi et al., 2001; Clément et al., 2006). Accordingly, a trade-off has been made to select simultaneously for udder floor position and milk production traits (Clément et al., 2006).

Except for udder depth, genetic correlations between cell counts and udder type traits are highly inconsistent in dairy cattle and sheep literature (Rupp and Boichard, 2003), which complicates comparisons across species. In the present goat study, genetic correlations between

Table 3. Heritability $\left(h^{2}\right)$ of milk production traits and genetic correlation $\left(\mathrm{r}_{\mathrm{g}}\right)$ with lactation SCS (LSCS) in primiparous goats

\begin{tabular}{lccrrr}
\hline & \multicolumn{2}{c}{$h^{2}$} & & \multicolumn{2}{c}{$\mathrm{r}_{\mathrm{g}}$ with LSCS } \\
\cline { 2 - 3 } \cline { 5 - 6 } Trait & Saanen & Alpine & & Saanen & \multicolumn{1}{c}{ Alpine } \\
\hline Milk yield, ${ }^{1} \mathrm{~kg}$ & $0.34 \pm 0.009$ & $0.30 \pm 0.008$ & & $0.12 \pm 0.026$ & $0.00 \pm 0.023$ \\
Protein yield, $\mathrm{kg}$ & $0.34 \pm 0.009$ & $0.31 \pm 0.008$ & & $0.06 \pm 0.025$ & $-0.04 \pm 0.023$ \\
Fat yield, $\mathrm{kg}$ & $0.35 \pm 0.009$ & $0.32 \pm 0.007$ & & $-0.02 \pm 0.024$ & $-0.13 \pm 0.022$ \\
Protein content, $\mathrm{kg} / \mathrm{L}$ & $0.60 \pm 0.009$ & $0.67 \pm 0.007$ & & $-0.13 \pm 0.022$ & $-0.06 \pm 0.022$ \\
Fat content, kg/L & $0.61 \pm 0.009$ & $0.62 \pm 0.007$ & & $-0.20 \pm 0.019$ & $-0.18 \pm 0.019$ \\
\hline
\end{tabular}

${ }^{1}$ In a 250-d lactation. 
Table 4. Mean and heritability $\left(h^{2}, \pm \mathrm{SE}\right)$ of udder type traits, and genetic correlation $\left(\mathrm{r}_{\mathrm{g}}, \pm \mathrm{SE}\right)$ with lactation SCS (LSCS) in 24,388 and 18,741 Alpine and Saanen goats

\begin{tabular}{|c|c|c|c|c|c|c|}
\hline Udder type trait ${ }^{1}$ & \multicolumn{2}{|c|}{ Mean (SD) } & \multicolumn{2}{|c|}{$h^{2}$} & \multicolumn{2}{|c|}{$r_{\mathrm{g}}$ with LSCS } \\
\hline Fore udder & $3.33(1.10)$ & $3.49(1.20)$ & $0.30 \pm 0.014$ & $0.25 \pm 0.018$ & $-0.16 \pm 0.034$ & $-0.01 \pm 0.040$ \\
\hline Udder floor position ${ }^{1}$ & $6.34(1.06)$ & $6.17(1.14)$ & $0.34 \pm 0.015$ & $0.37 \pm 0.018$ & $-0.24 \pm 0.032$ & $-0.19 \pm 0.036$ \\
\hline Udder profile $^{1}$ & $5.81(1.33)$ & $6.21(1.28)$ & $0.40 \pm 0.016$ & $0.28 \pm 0.017$ & $0.11 \pm 0.030$ & $-0.11 \pm 0.037$ \\
\hline Rear udder attachment ${ }^{1}$ & $4.96(1.36)$ & $5.35(1.49)$ & $0.23 \pm 0.015$ & $0.29 \pm 0.016$ & $-0.10 \pm 0.039$ & $-0.10 \pm 0.039$ \\
\hline Teat form & $4.90(1.30)$ & $4.92(1.40)$ & $0.27 \pm 0.016$ & $0.26 \pm 0.016$ & $-0.27 \pm 0.034$ & $-0.07 \pm 0.038$ \\
\hline Teat placement & $3.61(0.99)$ & $4.13(0.92)$ & $0.38 \pm 0.016$ & $0.30 \pm 0.017$ & $0.15 \pm 0.030$ & $-0.00 \pm 0.036$ \\
\hline Teat angle & $5.02(0.87)$ & $5.10(0.80)$ & $0.22 \pm 0.015$ & $0.20 \pm 0.016$ & $0.04 \pm 0.039$ & $-0.08 \pm 0.041$ \\
\hline Teat orientation & $3.67(0.89)$ & $4.07(0.84)$ & $0.35 \pm 0.016$ & $0.32 \pm 0.016$ & $0.13 \pm 0.032$ & $0.06 \pm 0.007$ \\
\hline
\end{tabular}

${ }^{1}$ Udder type trait currently included in the goat udder type index.

LSCS and type traits were highest for teat length, teat width, and teat form in the Alpine breed (Table 4), showing that, in this breed, the shortest and tightest teats are associated with the lowest LSCS. Teat length and width are strongly correlated with teat form: schematically, short and tight teats are cylindrical, whereas long and large teats are conic. Accordingly, goats with cylindrical teats have lower LSCS than goats with conic teats. Teat external anatomy might be associated with prevalence of mammary infections. However, further bacteriological status information of the mammary gland will be necessary to confirm this hypothesis. Correlations with teat traits were significantly $(P<0.05)$ lower in the Saanen breed than in the Alpine breed (Table 4).

\section{CONCLUSIONS}

In the present study, genetic parameters for the weighted lactation mean of somatic cell scores (LSCS) in Alpine and Saanen primiparous goats were reported. Estimates of heritability for SCS at the lactation level obtained in this study will allow implementation of genetic evaluation in the short term. Genetic correlations between LSCS and production traits were generally low. The LSCS trait was genetically favorably associated with tightly attached udders and, in the Saanen breed, with some teat characteristics. A reduction in SCS can be achieved by selection, with minor consequences on present genetic gains in milk production and udder type traits.

\section{ACKNOWLEDGMENTS}

Authors acknowledge Claire Proffit and Christine Bertrand from the CTIG (Processing Centre of Genetic Information, Jouy en Josas, France) for their assistance in providing SCC data.

\section{REFERENCES}

Ali, A., and G. Shook. 1980. An optimum transformation for somatic cell concentration in milk. J. Dairy Sci. 63:487-490.

Barillet, F., R. Rupp, S. Mignon-Grasteau, J. M. Astruc, and M. Jacquin. 2001. Genetic analysis for mastitis resistance and milk somatic cell score in French Lacaune dairy sheep. Genet. Sel. Evol. 33:397-415.

Bélichon, S., E. Manfredi, and A. Piacère. 1998. Genetic parameters of dairy traits in the Alpine and Saanen goat breeds. Genet. Sel. Evol. 30:529-534.

Bergonier, D., and X. Berthelot. 2003. New advances in epizootology and control of ewe mastitis. Livest. Prod. Sci. 79:1-16.

Bergonier, D., R. de Cremoux, R. Rupp, G. Lagriffoul, and X. Berthelot. 2003. Mastitis of dairy small ruminants. Vet. Res. 34:689-716.

Boettcher, P. J., P. Moroni, G. Pisoni, and D. Gianola. 2005. Application of a finite mixture model to somatic cell scores of Italian goats. J. Dairy Sci. 88:2209-2216.

Boichard, D., and R. Rupp. 1997. Genetic analysis and genetic evaluation for somatic cell score in French dairy cattle. Interbull Bull. 15:54-62.

Clément, V., B. Bibe, E. Verrier, J. M. Elsen, E. Manfredi, J. Bouix, and E. Hanocq. 2001. Simulation analysis to test the influence of model adequacy and data structure on the estimation of genetic parameters for traits with direct and maternal effects. Genet. Sel. Evol. 33:369-395.

Clément, V., D. Boichard, A. Piacère, A. Barbat, and E. Manfredi. 2002. Genetic evaluation of French goats for dairy and type traits. Pages 119-122 in Proc. 7th Congr. Genet. Appl. Livest. Prod., Montpellier, France. INRA, Castanet-Tolosan, France.

Clément, V., P. Martin, and F. Barillet. 2006. Elaboration of a total merit index combining dairy and udder type traits. Pages 209-212 in Proc. 13 èmes Rencontres Recherches Ruminants, Paris, France. INRA and Institut de l'Elevage, Paris, France.

Contreras, A., D. Sierra, J. Corrales, A. Sanchez, and J. Marco. 1996. Physiological threshold of somatic cell count and California Mastitis Test for diagnosis of caprine subclinical mastitis. Small Rumin. Res. 21:259-264.

De Crémoux, R., and B. Poutrel. 2001. Somatic cell count in goats milk: A tool in presumptive diagnosis of intramammary infections. Pages 757-760 in Proc. 7th International Conference on Goats, Tours, France. INRA, Nouzilly, and Institut de l'Elevage, Paris, France.

el-Saied, U., J. Carriedo, and L. De La Fuente. 1999. Genetic parameters of lactation cell counts and milk and protein yields in dairy ewes. J. Dairy Sci. 82:639-644.

Koop, G., N. Dik, M. Nielen, and L. Lipman. 2010. Short communication: Repeatability of differential goat bulk milk culture and associations with somatic cell count, total bacterial count, and standard plate count. J. Dairy Sci. 93:2569-2573. 
Legarra, A., and E. Ugarte. 2005. Genetic parameters of udder traits, somatic cell score, and milk yield in Latxa sheep. J. Dairy Sci. 88:2238-2245.

Luengo, C., A. Sánchez, J. C. Corrales, C. Fernández, and A. Contreras. 2004. Influence of intramammary infection and non-infection factors on somatic cell counts in dairy goats. J. Dairy Res. 71:169-174.

Manfredi, E., A. Piacere, P. Lahaye, and V. Ducrocq. 2001. Genetic parameters of type appraisal in Saanen and Alpine goats. Livest. Prod. Sci. 70:183-189.

Miglior, F., B. L. Muir, and B. J. Van Doormaal. 2005. Selection indices in Holstein cattle of various countries. J. Dairy Sci. 88:12551263

Moroni, P., G. Pisoni, G. Ruffo, and P. J. Boettcher. 2005. Risk factors for intramammary infections and relationship with somaticcell counts in Italian dairy goats. Prev. Vet. Med. 69:163-173.

Mrode, R., and G. Swanson. 1996. Genetic and statistical properties of somatic cell count and its suitability as an indirect means of reducing the incidence of mastitis in dairy cattle. Anim. Breed. Abstr. 64:847-857.

Neumaier, A., and E. Groeneveld. 1998. Restricted maximum likelihood estimation of covariances in sparse linear models. Genet. Sel. Evol. 30:3-26.

Paape, M. J., B. Poutrel, A. Contreras, J. C. Marco, and A. V. Capuco. 2001. Milk somatic cells and lactation in small ruminants. J. Dairy Sci. 84(E. Suppl.):E237-E244.

Poutrel, B., R. de Cremoux, M. Ducelliez, and D. Verneau. 1997. Control of intramammary infections in goats: Impact on somatic cell counts. J. Anim. Sci. 75:566-570.

Poutrel, B., and C. Lerondelle. 1983. Cell content of goat milk: California Mastitis Test, Coulter counter, and Fossomatic for predicting half infection. J. Dairy Sci. 66:2575-2579.
Reents, R., J. Jamrozik, L. R. Schaeffer, and J. C. Dekkers. 1995. Estimation of genetic parameters for test day records of somatic cell score. J. Dairy Sci. 78:2847-2857.

Riggio, V., R. Finocchiaro, J. B. van Kaam, B. Portolano, and H. Bovenhuis. 2007. Parameters for milk somatic cell score and relationships with production traits in primiparous dairy sheep. J. Dairy Sci. 90:1998-2003.

Rupp, R., B. Bergonier, S. Dion, M. C. Hygonenq, M. R. Aurel, C. Robert-Granié, and G. Foucras. 2009. Response to somatic cell count-based selection for mastitis resistance in a divergent selection experiment in sheep. J. Dairy Sci. 92:1203-1219.

Rupp, R., and D. Boichard. 1999. Genetic parameters for clinical mastitis, somatic cell score, production, udder type traits, and milking ease in first lactation Holsteins. J. Dairy Sci. 82:2198-2204.

Rupp, R., and D. Boichard. 2003. Genetics of resistance to mastitis in dairy cattle. Vet. Res. 34:671-688.

Rupp, R., D. Boichard, A. Barbat, J. Astruc, G. Lagriffoul, and F. Barillet. 2002. Selection for mastitis resistance in French dairy sheep. Pages 119-122 in Proc. 7th Congress on Genetic Applied to Livestock Production, Montpellier, France. INRA, CastanetTolosan, France.

Rupp, R., G. Lagriffoul, J. M. Astruc, and F. Barillet. 2003. Genetic parameters for milk somatic cell scores and relationships with production traits in French Lacaune dairy sheep. J. Dairy Sci. 86:1476-1481.

Serrano, M., M. Pérez-Guzmán, V. Montoro, and J. Jurado. 2003 Genetic analysis of somatic cell count and milk traits in Manchega ewes Mean lactation and test-day approaches. Livest. Prod. Sci. $84: 1-10$ 